\title{
Role of Integrated Nutrient Modules on Yield, Economics and Soil Characteristics of Banana cv. Grand Naine
}

\author{
T. Ganapathi* and P.R. Dharmatti \\ Department of Horticulture, University of Agricultural Sciences, Dharwad-580 005, \\ Karnataka, India \\ *Corresponding author
}

\section{Keywords \\ Banana, INM, \\ Nutrient module, Soil properties and NPK content in plant}

Article Info

Accepted:

14 December 2017

Available Online:

10 January 2018

\section{A B S T R A C T}

A field experiment was conducted at new orchard, Department of Horticulture, University of Agricultural Sciences, Dharwad during 2014-15 and 2015-16 on "Integrated nutrient management studies in banana cv. Grand Naine (AAA)" through application of different combination of organic manures and inorganic fertilizers with green manure, Azospirillum and PSB. The results revealed that, vermicompost equivalent to $40 \%$ RDN (24.20 t/ha) + Urea equivalent to $40 \% \operatorname{RDN}(535.73 \mathrm{~kg} / \mathrm{ha})+$ Green manure (sunnhemp @ $8.88 \mathrm{t} / \mathrm{ha}$ ) and Azospirillum (@30.86 kg/ha) equivalent to 20\% RDN + PSB (@30.86 kg/ha) $\left(\mathrm{T}_{7}\right)$ recorded the highest yield parameters \{bunch weight $(26.94 \mathrm{~kg})$, number of hands per bunch (11.75), finger weight $(137.38 \mathrm{~g})$, finger length $(17.75 \mathrm{~cm})$, plot yield $(85.57 \mathrm{~kg})$ and the yield per ha $(66.02 \mathrm{t})$ \}, gross returns (Rs.4.97 lakh/ha) and moderate net returns (Rs.3.04 lakh/ha) followed by $\mathrm{T}_{10}$ (Agrigold combination) and $\mathrm{T}_{11}$ (Bhumilabh combination) treatments. After the completion of the experiment the organic carbon was found to increase in organic treatments $\left(\mathrm{T}_{1}\right.$ to $\left.\mathrm{T}_{5}\right)$ from $0.65 \%$ to $0.72 \%$, whereas it was decreased from $0.65 \%$ to $0.57 \%$ in integrated treatments $\left(\mathrm{T}_{6}\right.$ to $\left.\mathrm{T}_{12}\right)$. The available nitrogen and potash was significantly higher in organic treatments than integrated treatments whereas the available phosphorous was decreased in organic treatments compared to integrated treatments.

\section{Introduction}

In India, banana is cultivated in an area of 0.83 million ha with a production of 30 million tonnes (Anon., 2011). The major banana growing areas are in Tamil Nadu, Maharashtra, Andhra Pradesh, Gujarat, Kerala, Karnataka, West Bengal and Orissa. It is being grown in an area of 1.12 lakh ha with a production of 2.28 lakh tonnes in Karnataka state.
Banana is known to consume more nutrients for its growth, yield and biomass production (Hazarika et al., 2015). The use of chemical fertilizers alone has deleterious effect on soil physical, chemical and biological properties and productivity in the long run.

The availability of organic manures is also one of the limitations for use in banana production. To fulfil the nutrient requirement only through organic or inorganic or bio- fertilizers alone is 
seldom possible but integration of all these sources will not only aid in achieving higher yield and returns but also in sustaining the soil fertility status in the long run.

\section{Materials and Methods}

The field experiment with an integrated nutrient module consisting of organic manures, chemical fertilizers, green manure and bio-fertilizer in banana cv. Grand Naine was conducted during 2014-15 and 2015-16 at new orchard, Department of Horticulture, University of Agricultural Sciences, Dharwad. The soil type was red with clay texture.

The experiment consists of 12 treatments viz.

\section{Plant crop}

$\mathrm{T}_{1}$. FYM equivalent to $40 \% \mathrm{RDN}(48.40 \mathrm{t} / \mathrm{ha})$ + VC equivalent to $40 \%$ RDN (24.20 t/ha) + GM (Sunnhemp @ 8.88 t/ha) and Azospirillum $(30.86 \mathrm{~kg} / \mathrm{ha}$ ) equivalent to $20 \% \mathrm{RDN}+\mathrm{PSB}$ (30.86 kg/ha).

$\mathrm{T}_{2}$-FYM equivalent to $40 \% \mathrm{RDN}(48.40 \mathrm{t} / \mathrm{ha})$ + PM equivalent to $40 \%$ RDN (8.96 t/ha) + GM (Sunnhemp @ 8.88 t/ha) and Azospirillum (30.86 kg/ha) equivalent to $20 \% \mathrm{RDN}+\mathrm{PSB}$ (30.86 kg/ha).

$\mathrm{T}_{3}$ - FYM equivalent to $40 \% \mathrm{RDN}$ (48.40 t/ha) + SM equivalent to $40 \%$ RDN (10.17 t/ha) + GM (Sunnhemp @ 8.88 t/ha) and Azospirillum (30.86 kg/ha) equivalent to $20 \% \mathrm{RDN}+\mathrm{PSB}$ (30.86 kg/ha).

$\mathrm{T}_{4}$. FYM equivalent to $40 \% \mathrm{RDN}$ (48.40 t/ha) + AG equivalent to $40 \%$ RDN (10.52 t/ha) + GM (Sunnhemp @ 8.88 t/ha) and Azospirillum $(30.86 \mathrm{~kg} / \mathrm{ha}$ ) equivalent to $20 \% \mathrm{RDN}+\mathrm{PSB}$ (30.86 kg/ha).

$\mathrm{T}_{5 \text { - }} \mathrm{FYM}$ equivalent to $40 \% \mathrm{RDN}$ (48.40 t/ha) + BL equivalent to $40 \% \mathrm{RDN}(7.56 \mathrm{t} / \mathrm{ha})+$
GM (Sunnhemp @ 8.88 t/ha) and Azospirillum (30.86 kg/ha) equivalent to $20 \% \mathrm{RDN}+\mathrm{PSB}$ (30.86 kg/ha).

$\mathrm{T}_{6-}$ FYM equivalent to $40 \% \mathrm{RDN}$ (48.40 t/ha) + $40 \%$ RDN through chemical fertilizer (Urea $535.73 \mathrm{~kg} / \mathrm{ha})+\mathrm{GM}$ (Sunnhemp @ $8.88 \mathrm{t} / \mathrm{ha})$ and Azospirillum $(30.86 \mathrm{~kg} / \mathrm{ha})$ equivalent to $20 \% \mathrm{RDN}+$ PSB (30.86 kg/ha).

$\mathrm{T}_{7 \text {. }} \mathrm{VC}$ equivalent to $40 \% \mathrm{RDN}(24.20 \mathrm{t} / \mathrm{ha})+$ $40 \%$ RDN through chemical fertilizer (Urea $535.73 \mathrm{~kg} / \mathrm{ha})+$ GM (Sunnhemp @ $8.88 \mathrm{t} / \mathrm{ha}$ ) and Azospirillum (30.86 kg/ha) equivalent to $20 \% \mathrm{RDN}+\mathrm{PSB}(30.86 \mathrm{~kg} / \mathrm{ha})$.

$\mathrm{T}_{8 \text { - }} \mathrm{PM}$ equivalent to $40 \% \mathrm{RDN}(8.96 \mathrm{t} / \mathrm{ha})+$ $40 \%$ RDN through chemical fertilizer (Urea $535.73 \mathrm{~kg} / \mathrm{ha}$ ) + GM (Sunnhemp @ $8.88 \mathrm{t} / \mathrm{ha}$ ) and Azospirillum $(30.86 \mathrm{~kg} / \mathrm{ha})$ equivalent to $20 \% \mathrm{RDN}+$ PSB (30.86 kg/ha).

$\mathrm{T}_{9-} \mathrm{SM}$ equivalent to $40 \% \mathrm{RDN}(10.17 \mathrm{t} / \mathrm{ha})+$ $40 \%$ RDN through chemical fertilizer (Urea $535.73 \mathrm{~kg} / \mathrm{ha})+$ GM (Sunnhemp @ $8.88 \mathrm{t} / \mathrm{ha}$ ) and Azospirillum (30.86 kg/ha) equivalent to $20 \% \mathrm{RDN}+\mathrm{PSB}(30.86 \mathrm{~kg} / \mathrm{ha})$.

$\mathrm{T}_{10-}$ AG equivalent to $40 \% \mathrm{RDN}$ (10.52 t/ha) + $40 \%$ RDN through chemical fertilizer (Urea $535.73 \mathrm{~kg} / \mathrm{ha})+\mathrm{GM}$ (Sunnhemp @ $8.88 \mathrm{t} / \mathrm{ha}$ ) and Azospirillum (30.86 kg/ha) equivalent to $20 \% \mathrm{RDN}+\mathrm{PSB}(30.86 \mathrm{~kg} / \mathrm{ha})$

$\mathrm{T}_{11}$. BL equivalent to $40 \% \mathrm{RDN}(7.56 \mathrm{t} / \mathrm{ha})+$ $40 \%$ RDN through chemical fertilizer (Urea $535.73 \mathrm{~kg} / \mathrm{ha}$ ) + GM (Sunnhemp @ $8.88 \mathrm{t} / \mathrm{ha}$ ) and Azospirillum (30.86 kg/ha) equivalent to $20 \% \mathrm{RDN}+\mathrm{PSB}(30.86 \mathrm{~kg} / \mathrm{ha})$

$\mathrm{T}_{12}$-Control (RDF 200: 100: $300 \mathrm{~g}$ NPK /plant or 617.20:308.60: $925.80 \mathrm{~kg} \mathrm{NPK/ha} \mathrm{+} \mathrm{Farm}$ yard manure@ 40 t/ha)

The recommended dose of phosphorous and potash $(100 \mathrm{~g} / \mathrm{plant}$ and $300 \mathrm{~g} / \mathrm{plant}$ 
respectively) was supplied through DAP and MOP.

\section{Ratoon crop}

$\mathrm{RDF}=100: 50: 100 \mathrm{NPK} \mathrm{g} /$ plant or 308.60:154.20: 308.60 kg NPK/ha) +FYM @ $20 \mathrm{t} / \mathrm{ha}$

Note: 1) FYM- Farm Yard Manure, VCVermicompost, PM-Poultry Manure, SMSheep Manure, AG-Agrigold, BL-Bhumilabh, GM-Green manure, PSB-Phosphate Solubilizing bacteria. Azospirillum (ACD-15) and PSB (Pseudomonas striata) were used for the study.

The application of organic manures, chemical fertilizers with green manure and bio-fertilizer will compensate the majority of the plant nutrition thereby increase the productivity of banana cv. Grand Naine. The influence was assessed on yield, soil characteristics and economics of banana. The results of the field experiments conducted during the year 201415 and 2015-16 are pooled and discussed.

\section{Results and Discussion}

The results of pooled mean of the field experiments conducted during the year 201415 and 2015-16 are discussed under different headings.

Effect of different sources of nutrient modules on yield parameters of banana (Table 1)

The influence of different sources of nutrient modules on yield parameters which caused the yield variations are discussed here under.

The pooled data indicated that, the maximum mean yield of banana per hectare (66.02 t/ha) was recorded in $\mathrm{T}_{7}$ \{Vermicompost equivalent to $40 \% \operatorname{RDN}(24.20 \mathrm{t} / \mathrm{ha})+$ Chemical fertilizer (Urea $535.73 \mathrm{~kg} / \mathrm{ha}$ ) equivalent to 40 $\%$ RDN + Green manure (Sunnhemp @ 8.88 t/ha) + Azospirillum (30.86 kg/ha) equivalent to $20 \% \mathrm{RDN}+\mathrm{PSB}(30.86 \mathrm{~kg} / \mathrm{ha})\}$ which was on par with $\mathrm{T}_{1}, \mathrm{~T}_{10}$ and $\mathrm{T}_{11}$ and significantly superior over rest of the treatments (Table 1).

The highest mean yield of banana in $T_{7}$ was attributed to the higher growth and yield contributing parameters. The mean yield components of banana indicated that the maximum bunch weight $(26.94 \mathrm{~kg})$, number of hands per bunch (11.75), finger weight $(137.38 \mathrm{~g})$, finger length $(17.75 \mathrm{~cm})$, number of fingers on third hand (16.93) were recorded in plants applied with vermicompost equivalent to $40 \% \operatorname{RDN}(24.20 \mathrm{t} / \mathrm{ha})+$ Chemical fertilizer (Urea $535.73 \mathrm{~kg} / \mathrm{ha}$ ) equivalent to $40 \% \mathrm{RDN}+$ Green manure (sunnhemp @ 8.88 t/ha) and Azospirillum (30.86 kg/ha) equivalent to $20 \% \mathrm{RDN}+\mathrm{PSB}$ (30.86 kg/ha) $\left(\mathrm{T}_{7}\right)$ (Table 1$)$.

The similar results were also recorded with integrated nutrient modules by many scientists in banana. Athani et al., (1999) reported that, maximum number of fingers per bunch, bunch weight $(5.10 \mathrm{~kg} / \mathrm{bunch})$ and finally fruit yield (15.14 t/ha) was obtained by applying $50 \%$ $\mathrm{RDF}+$ vermicompost $2.00 \mathrm{~kg} / \mathrm{plant}$ in Rajapuri banana. They also reported that, organic matter in the form of vermicompost in combination with inorganic fertilizers increased the yield in banana cv. Rajapuri. Nachegowda et al., (2004) reported that, plants applied with $15 \mathrm{~kg}$ FYM + 180:108:220g NPK/plant/year recorded the highest bunch weight $(49.47 \mathrm{~kg})$, fruit length $(25.19 \mathrm{~cm})$, fruit weight $(220.21 \mathrm{~g})$, finger /hand (19.00), fingers/bunch (227.94) and the yield $(148.41 \mathrm{t} / \mathrm{ha})$ in banana followed by 2.5 $\mathrm{kg}$ Sheep manure +108:108:2205g NPK /plant/year. Hazarika et al., (2011) reported that, the highest number of fingers per hand (22.87), finger length $(22.97 \mathrm{~cm})$, circumference $(14.13 \mathrm{~cm})$, finger volume 
(282.98 cc) and weight of finger (231.67 g) were significantly influenced by $100 \%$ RDF +VAM (50 g/plant) + Azospirillum (50 g/plant $)+$ PSB (50 g/plant) + Trichoderma harjianum (50 g/plant) in banana.

Patil and Shinde (2013) recorded the highest bunch weight of $19.31 \mathrm{~kg}$ in plants inoculated with $75 \% \mathrm{RDF}+\mathrm{FYM}+$ Azotobacter $(50 \mathrm{~g}$ /plant $)+$ PSB (50 g /plant) + VAM (250 $\mathrm{g} /$ plant) in Ardhapuri cultivar of banana. They also reported that, the highest yield of 85.80 t/ha obtained when the plants were treated with $50 \% \mathrm{RDF}+\mathrm{FYM}+$ Azatobacter (50 g/plant $)+$ PSB (50 g/plant) + VAM (250 $\mathrm{g} /$ plant) in banana cv. Ardhapuri (AAA).

Significant increase in number of fingers per bunch and average bunch weight of $5.0 \mathrm{~kg}$ by applying vermicompost $+\mathrm{N}$ as inorganic fertilizer in banana reported by Manivannan and Selvamani (2014). They also reported that, maximum bunch weight, more number of fingers per bunch was obtained by applying vermicompost as full $\mathrm{N}$ in banana. They also opined that, significantly more finger weight, finger girth was obtained by applying organic + inorganic fertilizers. The maximum number of fingers per bunch, bunch weight (5.10 $\mathrm{kg} / \mathrm{bunch})$ and finally fruit yield (15.14 t/ha) by applying $50 \% \mathrm{RDF}+$ vermicompost 2.00 $\mathrm{kg} / \mathrm{plant}$ in banana.

\section{Effect of different sources of nutrient modules on soil properties (Table 2)}

At the start of experiment, the organic carbon $(0.65 \%)$ and available NPK were medium $(285,28.75$ and $156.25 \mathrm{~kg} / \mathrm{ha})$. The soil $\mathrm{pH}$ was neutral (7.38) and EC (0.25 dS/m) was non saline. The results of the pooled data indicated that, the organic carbon was found to enhance in organic treatments $\left(\mathrm{T}_{1}\right.$ to $\left.\mathrm{T}_{5}\right)$ from $0.65 \%$ to $0.72 \%$, whereas it was decreased from $0.65 \%$ to $0.57 \%$ in integrated treatments $\left(\mathrm{T}_{6}\right.$ to $\left.\mathrm{T}_{12}\right)$. The available $\mathrm{N}$ in soil was significantly higher in organic treatments than integrated treatments. The available phosphorous was decreased in organic treatments compared to integrated treatments. The available potash recorded higher status in integrated nutrient modules compared to organic modules except $\mathrm{T}_{1}, \mathrm{~T}_{4}$ and $\mathrm{T}_{5}$ (Table 2).

The combined application of inorganic fertilizer and bio-fertilizers in banana significantly increased the available NPK status and organic $\mathrm{C}$ in soil after harvest (Hazarika et al., 2011). The integrated use of organics with $100 \%$ recommended dose of NPK (P as rock phosphate) along with biofertilizers increased nitrogen, phosphorus and potassium concentration availability in the soil after harvest in banana (Hazarika et al., 2015).

The results of the present study were in line with Hazarika et al., (2011). They reported that, the least $\mathrm{pH}$ was recorded in soils where the plants applied with $100 \%$ RDF + Vermicompost (4.69) and the highest organic carbon $0.85 \%$, available nitrogen 296.64 (kg/ha), available $\mathrm{P}_{2} \mathrm{O}_{5} 37.33$ (kg/ha) and available $\mathrm{K}_{2} \mathrm{O} 223.66$ (kg/ha).

The results of the present study also indicated increase in available nitrogen status in organic nutrient modules (Angelova et al., 2013). However, in integrated nutrient modules the nitrogen status was found to decline. This may be attributed to the higher uptake of nutrients resulted in higher yields in integrated treatments as compared to organic treatments. Available phosphorus decreased due to application of organics to soil (Angelova et $a l ., 2013)$. This indicates that, the application of organics would reduce the available phosphorous as found in the present study. The combined application of vermicompost with NPK fertilizers resulted in higher content of phosphorous as compared to FYM in combination with NPK fertilizers or control. 
Table.1 Influence of different sources of nutrient modules on yield parameters in banana cv. Grand Naine (Pooled mean)

\begin{tabular}{|c|c|c|c|c|c|c|c|}
\hline Treatments & $\begin{array}{c}\text { Bunch weight. } \\
\text { (kg) }\end{array}$ & $\begin{array}{l}\text { No. of hands } \\
\text { per bunch }\end{array}$ & $\begin{array}{c}\text { Finger weight. } \\
\text { (g) }\end{array}$ & $\begin{array}{l}\text { Finger length } \\
\text { (cm) }\end{array}$ & $\begin{array}{l}\text { No. of Fingers on } \\
3^{\text {rd }} \text { hand }\end{array}$ & Plot yield (kg) & Yield (t/ha) \\
\hline$T_{1}$ & 18.17 & 10.06 & 124.27 & 16.14 & 14.89 & 73.21 & 56.48 \\
\hline $\mathbf{T}_{2}$ & 14.58 & 9.10 & 117.77 & 15.23 & 13.88 & 60.44 & 46.63 \\
\hline $\mathbf{T}_{3}$ & 11.55 & 8.58 & 104.28 & 14.36 & 13.10 & 58.35 & 45.02 \\
\hline $\mathbf{T}_{4}$ & 17.85 & 10.31 & 123.43 & 15.32 & 14.26 & 72.72 & 56.10 \\
\hline $\mathbf{T}_{5}$ & 16.41 & 9.73 & 120.39 & 15.55 & 14.19 & 70.04 & 54.04 \\
\hline$T_{6}$ & 19.18 & 10.02 & 129.53 & 16.12 & 15.02 & 70.52 & 54.40 \\
\hline $\mathbf{T}_{7}$ & 26.94 & 11.75 & 137.38 & 17.75 & 16.93 & 85.57 & 66.02 \\
\hline$T_{8}$ & 12.85 & 9.54 & 104.43 & 14.40 & 13.09 & 61.69 & 47.59 \\
\hline $\mathbf{T}_{9}$ & 19.54 & 10.19 & 129.83 & 16.12 & 15.04 & 70.83 & 54.64 \\
\hline $\mathbf{T}_{10}$ & 23.69 & 10.98 & 135.91 & 17.18 & 16.12 & 84.27 & 65.01 \\
\hline $\mathrm{T}_{11}$ & 22.51 & 10.49 & 135.16 & 17.07 & 16.14 & 73.66 & 56.83 \\
\hline$T_{12}$ & 19.17 & 9.70 & 128.02 & 16.66 & 15.68 & 71.21 & 54.94 \\
\hline S Em+/- & 0.65 & 0.15 & 1.84 & 0.31 & 0.30 & 4.28 & 3.30 \\
\hline $\mathrm{CD}$ at $5 \%$ & 1.91 & 0.44 & 5.39 & 0.90 & 0.87 & 12.55 & 9.68 \\
\hline
\end{tabular}

T. FYM equivalent to 40 \% RDN (48.40 t/ha) + VC equivalent to 40 \% RDN (24.20 t/ha) + GM (sunnhemp @ 8.88 t/ha) and Azospirillum (@ 30.86 kg/ha) equivalent to $20 \%$ RDN + PSB (@ 30.86 $\mathrm{kg} / \mathrm{ha})$.

T2-FYM equivalent to 40 \% RDN (48.40 t/ha) + PM equivalent to 40 \% RDN (8.96 t/ha) + GM (sunnhemp @ 8.88 t/ha) and Azospirillum (@ 30.86 kg/ha) equivalent to 20\% RDN + PSB (@ 30.86 $\mathrm{kg} / \mathrm{ha})$.

$\mathrm{T}_{3-}$ FYM equivalent to 40 \% RDN (48.40 t/ha) + SM equivalent to 40 \% RDN (10.17 t/ha) + GM (sunnhemp @ 8.88 t/ha) and Azospirillum (@ 30.86 kg/ha) equivalent to $20 \%$ RDN + PSB (@ 30.86 $\mathrm{kg} / \mathrm{ha}$ ).

T.-FYM equivalent to 40 \% RDN (48.40 t/ha) + AG equivalent to 40 \% RDN (10.52 t/ha) + GM (sunnhemp @ 8.88 t/ha) and Azospirillum (@ 30.86 kg/ha) equivalent to $20 \%$ RDN + PSB (@ 30.86 $\mathrm{kg} / \mathrm{ha})$.

T5. FYM equivalent to 40 \% RDN (48.40 t/ha) + BL equivalent to 40 \% RDN (7.56 t/ha)+GM (Sunnhemp @ 8.88 t/ha) and Azospirillum (@ 30.86 kg/ha) equivalent to $20 \%$ RDN + PSB (@30.86 $\mathrm{kg} / \mathrm{ha})$.

$\mathrm{T}_{6}$ FYM equivalent to $40 \%$ RDN (48.40 t/ha) + 40 \% RDN through chemical fertilizer (urea $535.73 \mathrm{~kg} / \mathrm{ha}$ ) + GM (sunnhemp @ $8.88 \mathrm{t} / \mathrm{ha}$ ) and Azospirillum (@ $\left.30.86 \mathrm{~kg} / \mathrm{ha}\right)$ equivalent to $20 \%$ RDN + PSB (@ $30.86 \mathrm{~kg} / \mathrm{ha})$.

T7. VC equivalent to $40 \%$ RDN (24.20 t/ha) + 40 \% RDN through chemical fertilizer (urea $535.73 \mathrm{~kg} / \mathrm{ha}$ ) + GM (sunnhemp@ 8.88 t/ha) and Azospirillum (@ $30.86 \mathrm{~kg} / \mathrm{ha}$ ) equivalent to $20 \%$ RDN + PSB (@ $30.86 \mathrm{~kg} / \mathrm{ha})$.

$\mathrm{T}_{8 \text {. }}$ PM equivalent to $40 \%$ RDN (8.96 t/ha)+ $40 \%$ RDN through chemical fertilizer (urea $535.73 \mathrm{~kg} / \mathrm{ha}$ ) + GM (sunnhemp @ 8.88 t/ha) and Azospirillum (@ $30.86 \mathrm{~kg} / \mathrm{ha}$ ) equivalent to $20 \%$ RDN + PSB (@30.86 kg/ha).

T. SM equivalent to $40 \%$ RDN (10.17 t/ha) + $40 \%$ RDN through chemical fertilizer (urea $535.73 \mathrm{~kg} / \mathrm{ha}$ ) + GM (sunnhemp @ $8.88 \mathrm{t} / \mathrm{ha})$ and Azospirillum (@ $30.86 \mathrm{~kg} / \mathrm{ha}$ ) equivalent to $20 \% \mathrm{RDN}+$ PSB (@30.86 kg/ha).

$\mathrm{T}_{10}$ - AG equivalent to $40 \% \mathrm{RDN}$ (10.52 t/ha) + 40 \% RDN through chemical fertilizer (urea $535.73 \mathrm{~kg} / \mathrm{ha}$ ) + GM (sunnhemp @ 8.88 t/ha) and Azospirillum (@ $30.86 \mathrm{~kg} / \mathrm{ha}$ ) equivalent to 20\% RDN + PSB (@30.86 kg/ha

$\mathrm{T}_{11}$. BL equivalent to $40 \% \mathrm{RDN}$ (7.56 t/ha) + $40 \%$ RDN through chemical fertilizer (urea $535.73 \mathrm{~kg} / \mathrm{ha}$ ) + GM (sunnhemp @ 8.88 t/ha) and Azospirillum (@ $30.86 \mathrm{~kg} / \mathrm{ha}$ ) equivalent to $20 \% \mathrm{RDN}+$ PSB (@ $30.86 \mathrm{~kg} / \mathrm{ha})$

$\mathrm{T}_{12}$-Control (RDF=617.20:308.60: $925.80 \mathrm{~kg} \mathrm{NPK} / \mathrm{ha}+$ Farm yard manure@ $40 \mathrm{t} / \mathrm{ha}$ (plant crop)

Ratoon crop: RDF=308.60:154.20: $308.60 \mathrm{~kg} \mathrm{NPK/ha)} \mathrm{+} \mathrm{FYM} \mathrm{@} \mathrm{20/ha} \mathrm{accordingly} \mathrm{it} \mathrm{has} \mathrm{been} \mathrm{supplied} \mathrm{through} \mathrm{different} \mathrm{sources}$

FYM- Farmyard manure, VC-Vermicompost, PM-Poultry manure, SM-Sheep manure, AG-Agrigold, BL-Bhumilabh, GM-Green manure, PSB-Phosphate Solubilizing bacteria 
Table.2 Influence of different sources of nutrient modules on economics of cultivation of banana cv. Grand Naine (Pooled mean)

\begin{tabular}{|c|c|c|c|c|}
\hline Treatments & GC (Rs) & GR (Rs) & NR (Rs) & B:C ratio \\
\hline $\mathbf{T}_{1}$ & $1,72,070$ & $4,25,377$ & $2,53,307$ & 2.45 \\
\hline $\mathbf{T}_{2}$ & $1,41,057$ & $3,51,422$ & $2,10,365$ & 2.49 \\
\hline $\mathbf{T}_{3}$ & $1,47,347$ & $3,39,108$ & $1,91,761$ & 2.30 \\
\hline $\mathbf{T}_{4}$ & $1,84,279$ & $4,22,733$ & $2,38,454$ & 2.29 \\
\hline $\mathbf{T}_{5}$ & $2,07,715$ & $4,06,747$ & $1,99,032$ & 1.96 \\
\hline $\mathrm{T}_{6}$ & $1,68,454$ & $4,09,822$ & $2,41,368$ & 2.43 \\
\hline $\mathbf{T}_{7}$ & $1,92,654$ & $4,97,621$ & $3,04,967$ & 2.58 \\
\hline$T_{8}$ & $1,29,016$ & $3,58,638$ & $2,29,622$ & 2.78 \\
\hline$T_{9}$ & $1,35,306$ & $4,11,605$ & $2,76,299$ & 3.04 \\
\hline $\mathbf{T}_{10}$ & $1,72,238$ & $4,90,095$ & $3,17,857$ & 2.85 \\
\hline $\mathrm{T}_{11}$ & $1,95,674$ & $4,28,279$ & $2,32,605$ & 2.19 \\
\hline $\mathbf{T}_{12}$ & $1,21,164$ & $4,13,830$ & $2,92,667$ & 3.42 \\
\hline S Em+/- & - & 24394 & 24395 & 0.14 \\
\hline CD at $5 \%$ & - & 71546 & 71546 & 0.41 \\
\hline
\end{tabular}

Banana fruit selling price (Rs/t): plant crop Rs.8,000 and ratoon crop Rs.7,000

GC: Gross cost, GR: Gross returns, NR: Net returns and B: C ratio benefit : cost ratio

$\mathrm{T}_{1 .}$ FYM equivalent to 40 \% RDN (48.40 t/ha) + VC equivalent to 40 \% RDN (24.20 t/ha)+ GM (sunnhemp @ 8.88 t/ha) and Azospirillum (@30.86 kg/ha) equivalent to $20 \%$ RDN + PSB (@ 30.86 $\mathrm{kg} / \mathrm{ha})$.

T2-FYM equivalent to 40 \% RDN (48.40 t/ha) + PM equivalent to 40 \% RDN (8.96 t/ha) + GM (sunnhemp @ 8.88 t/ha) and Azospirillum (@ 30.86 kg/ha) equivalent to $20 \%$ RDN + PSB (@ 30.86 $\mathrm{kg} / \mathrm{ha})$.

T3. FYM equivalent to 40 \% RDN (48.40 t/ha) + SM equivalent to 40 \% RDN (10.17 t/ha) + GM (sunnhemp @ 8.88 t/ha) and Azospirillum (@ 30.86 kg/ha) equivalent to 20 \% RDN + PSB (@30.86 $\mathrm{kg} / \mathrm{ha})$.

T. FYM equivalent to 40 \% RDN (48.40 t/ha)+AG equivalent to 40 \% RDN (10.52 t/ha)+GM (sunnhemp @ 8.88 t/ha) and Azospirillum (@ 30.86 kg/ha) equivalent to 20 \% RDN + PSB (@30.86 $\mathrm{kg} / \mathrm{ha})$.

T5- FYM equivalent to 40 \% RDN (48.40 t/ha) + BL equivalent to 40 \% RDN (7.56 t/ha) + GM (Sunnhemp @ 8.88 t/ha) and Azospirillum (@ 30.86 kg/ha) equivalent to 20\% RDN + PSB (@ 30.86 $\mathrm{kg} / \mathrm{ha}$ ).

$\mathrm{T}_{6}$ FYM equivalent to $40 \% \mathrm{RDN}$ (48.40 t/ha) + $40 \%$ RDN through chemical fertilizer (urea $535.73 \mathrm{~kg} / \mathrm{ha}$ ) + GM (sunnhemp @ $8.88 \mathrm{t} / \mathrm{ha}$ ) and Azospirillum (@ $\left.30.86 \mathrm{~kg} / \mathrm{ha}\right)$ equivalent to $20 \% \mathrm{RDN}+$ PSB (@ $30.86 \mathrm{~kg} / \mathrm{ha})$.

$\mathrm{T}_{7 .}$ VC equivalent to $40 \% \mathrm{RDN}$ (24.20 t/ha) + 40 \% RDN through chemical fertilizer (urea $535.73 \mathrm{~kg} / \mathrm{ha}$ ) + GM (sunnhemp@ 8.88 t/ha) and Azospirillum (@ $30.86 \mathrm{~kg} / \mathrm{ha}$ ) equivalent to $20 \%$ RDN + PSB (@ $30.86 \mathrm{~kg} / \mathrm{ha})$.

$\mathrm{T}_{8 \text { - }}$ PM equivalent to $40 \% \mathrm{RDN}(8.96 \mathrm{t} / \mathrm{ha})+40 \% \mathrm{RDN}$ through chemical fertilizer (urea $535.73 \mathrm{~kg} / \mathrm{ha}$ ) + GM (sunnhemp @ $8.88 \mathrm{t} / \mathrm{ha}$ ) and Azospirillum (@ $\left.30.86 \mathrm{~kg} / \mathrm{ha}\right)$ equivalent to $20 \% \mathrm{RDN}+$ PSB (@30.86 kg/ha).

T. SM equivalent to $40 \%$ RDN (10.17 t/ha) + $40 \%$ RDN through chemical fertilizer (urea 535.73 kg/ ha) + GM (sunnhemp @8.88 t/ha) and Azospirillum (@ 30.86 kg/ha) equivalent to $20 \%$ RDN + PSB (@ $30.86 \mathrm{~kg} / \mathrm{ha})$.

$\mathrm{T}_{10}$. AG equivalent to $40 \%$ RDN (10.52 t/ha) + 40 \% RDN through chemical fertilizer (urea $535.73 \mathrm{~kg} / \mathrm{ha}$ ) + GM (sunnhemp @ 8.88 t/ha) and Azospirillum (@ $30.86 \mathrm{~kg} / \mathrm{ha}$ ) equivalent to 20\% RDN + PSB (@30.86 kg/ha

$\mathrm{T}_{11}$. BL equivalent to $40 \%$ RDN (7.56 t/ha) + $40 \%$ RDN through chemical fertilizer (urea $535.73 \mathrm{~kg} / \mathrm{ha}$ ) + GM (sunnhemp @ 8.88 t/ha) and Azospirillum (@ $30.86 \mathrm{~kg} / \mathrm{ha}$ ) equivalent to $20 \%$ RDN + PSB (@ $30.86 \mathrm{~kg} / \mathrm{ha})$

$\mathrm{T}_{12}$-Control (RDF=617.20:308.60: $925.80 \mathrm{~kg} \mathrm{NPK} / \mathrm{ha}+$ Farm yard manure@ 40 t/ha (plant crop)

Ratoon crop: RDF=308.60:154.20: $308.60 \mathrm{~kg} \mathrm{NPK/ha)} \mathrm{+} \mathrm{FYM} \mathrm{@} \mathrm{20/ha} \mathrm{accordingly} \mathrm{it} \mathrm{has} \mathrm{been} \mathrm{supplied} \mathrm{through} \mathrm{different} \mathrm{sources}$

FYM- Farmyard manure, VC-Vermicompost, PM-Poultry manure, SM-Sheep manure, AG-Agrigold, BL-Bhumilabh, GM-Green manure, PSB-Phosphate Solubilizing bacteria 
Table.3 Influence of different sources of nutrient modules on soil characteristics in banana cv. Grand Naine (Pooled mean)

\begin{tabular}{|c|c|c|c|c|c|c|}
\hline Treatments & Soil pH (1:2.5) & $\mathrm{EC}(\mathrm{dS} / \mathrm{m})$ & Organic C (\%) & Avail N (kg/ha) & $\begin{array}{c}\text { Avail } \mathrm{P}_{2} \mathrm{O}_{5} \\
(\mathrm{~kg} / \mathrm{ha})\end{array}$ & Avail $K_{2} O(\mathrm{Kg} / \mathrm{ha})$ \\
\hline $\mathbf{T}_{1}$ & 7.24 & 0.14 & 0.72 & 319.95 & 24.05 & 133.50 \\
\hline $\mathbf{T}_{2}$ & 7.27 & 0.11 & 0.68 & 302.95 & 22.50 & 118.80 \\
\hline $\mathbf{T}_{3}$ & 7.34 & 0.12 & 0.69 & 306.68 & 23.90 & 118.65 \\
\hline $\mathrm{T}_{4}$ & 7.16 & 0.12 & 0.70 & 311.25 & 21.55 & 133.35 \\
\hline $\mathrm{T}_{5}$ & 6.98 & 0.16 & 0.71 & 314.98 & 23.90 & 132.90 \\
\hline $\mathrm{T}_{6}$ & 6.93 & 0.11 & 0.57 & 264.48 & 28.20 & 118.90 \\
\hline $\mathbf{T}_{7}$ & 6.91 & 0.11 & 0.59 & 271.53 & 30.70 & 130.85 \\
\hline $\mathrm{T}_{8}$ & 7.37 & 0.10 & 0.58 & 268.20 & 26.30 & 125.80 \\
\hline $\mathrm{T}_{9}$ & 7.07 & 0.14 & 0.59 & 271.10 & 28.20 & 118.60 \\
\hline$T_{10}$ & 7.04 & 0.12 & 0.61 & 281.88 & 29.30 & 123.65 \\
\hline$T_{11}$ & 7.20 & 0.11 & 0.59 & 271.93 & 28.80 & 130.85 \\
\hline $\mathbf{T}_{12}$ & 7.11 & 0.16 & 0.63 & 285.18 & 30.70 & 130.40 \\
\hline S Em+/- & 0.02 & 0.01 & 0.01 & 1.73 & 0.80 & 0.68 \\
\hline CD at $5 \%$ & 0.06 & 0.02 & 0.01 & 5.08 & 2.36 & 2.00 \\
\hline
\end{tabular}

T1. FYM equivalent to 40\% RDN (48.40 t/ha) + VC equivalent to 40\% RDN (24.20 t/ha) + GM (sunnhemp @ 8.88 t/ha) and Azospirillum (@ 30.86 kg/ha) equivalent to 20\% RDN + PSB (@ 30.86 $\mathrm{kg} / \mathrm{ha}$ ).

$\mathrm{T}_{2}$-FYM equivalent to 40\% RDN (48.40 t/ha) + PM equivalent to 40\% RDN (8.96 t/ha) + GM (sunnhemp @ 8.88 t/ha) and Azospirillum (@ 30.86 kg/ha) equivalent to 20\% RDN + PSB (@ 30.86 $\mathrm{kg} / \mathrm{ha}$ ).

T3-FYM equivalent to 40\% RDN (48.40 t/ha) + SM equivalent to 40\% RDN (10.17 t/ha)+ GM (sunnhemp @ 8.88 t/ha) and Azospirillum (@ 30.86 kg/ha) equivalent to 20\% RDN + PSB (@ 30.86

$\mathrm{kg} / \mathrm{ha}$ ).

T. FYM equivalent to 40\% RDN (48.40 t/ha) + AG equivalent to 40\% RDN (10.52 t/ha) + GM (sunnhemp @ 8.88 t/ha) and Azospirillum (@30.86kg/ha) equivalent to 20\% RDN + PSB (@ $30.86 \mathrm{~kg} / \mathrm{ha})$.

$\mathrm{T}_{5-}$ FYM equivalent to 40\% RDN (48.40 t/ha) + BL equivalent to 40\% RDN (7.56 t/ha) + GM (Sun hemp @ 8.88 t/ha) and Azospirillum (@ 30.86kg/ha) equivalent to 20\% RDN + PSB (@ 30.86kg/ha). $\mathrm{T}_{6}$ FYM equivalent to 40\% RDN (48.40 t/ha) + 40\% RDN through chemical fertilizer (Urea 535.73 kg/ ha) + GM (sunnhemp @8.88 t/ha) and Azospirillum (@30.86 kg/ha) equivalent to 20\% RDN + PSB (@ 30.86kg/ha).

T7. VC equivalent to 40\% RDN (24.20 t/ha) + 40\% RDN through chemical fertilizer (Urea $535.73 \mathrm{~kg} / \mathrm{ha}$ ) + GM (sunnhemp@ 8.88 t/ha) + Azospirillum (@ 30.86kg/ha) equivalent to 20\% RDN + PSB (@ $30.86 \mathrm{~kg} / \mathrm{ha})$.

T . PM equivalent to 40\% RDN (8.96 t/ha)+ 40\% RDN through chemical fertilizer (Urea $535.73 \mathrm{~kg} / \mathrm{ha}$ ) + GM (sunnhemp @ 8.88 t/ha) and Azospirillum (@ 30.86 kg/ha) equivalent to 20\% RDN + PSB (@ $30.86 \mathrm{~kg} / \mathrm{ha})$.

T. SM equivalent to 40\% RDN (10.17 t/ha) + 40\% RDN through chemical fertilizer (Urea $535.73 \mathrm{~kg} / \mathrm{ha}$ ) + GM (sunnhemp @ 8.88 t/ha) and Azospirillum (@ $30.86 \mathrm{~kg} / \mathrm{ha}$ ) equivalent to 20\% RDN + PSB (@ $30.86 \mathrm{~kg} / \mathrm{ha})$.

$\mathrm{T}_{10}$. AG equivalent to 40\% RDN (10.52 t/ha) + 40\% RDN through chemical fertilizer (Urea $535.73 \mathrm{~kg} / \mathrm{ha}$ ) + GM (sunnhemp @8.88 t/ha) and Azospirillum (@ $30.86 \mathrm{~kg} / \mathrm{ha}$ ) equivalent to 20\% RDN + PSB (@30.86 kg/ha

$\mathrm{T}_{11-}$ BL equivalent to 40\% RDN (7.56 t/ha) + 40\% RDN through chemical fertilizer (Urea $535.73 \mathrm{~kg} / \mathrm{ha}$ ) + GM (sunnhemp @ 8.88 t/ha) and Azospirillum (@30.86 kg/ha) equivalent to 20\% RDN + PSB (@30.86 kg/ha)

$\mathrm{T}_{12}$-Control (RDF=617.20:308.60: $925.80 \mathrm{~kg} \mathrm{NPK/ha}+$ Farm yard manure@ 40 t/ha (plant crop)

Ratoon crop: RDF=308.60:154.20: 308.60 kg NPK/ha) + FYM @ 20/ha accordingly it has been supplied through different sources

FYM- Farmyard manure, VC-Vermicompost, PM-Poultry manure, SM-Sheep manure, AG-Agrigold, BL-Bhumilabh, GM-Green manure, PSB-Phosphate Solubilizing bacteria 
Higher levels of available phosphorous in the treatments which received either vermicompost or FYM in combination with chemical fertilizers than control. Similar results were also recorded in the present study where integrated nutrient modules were imposed compared to organic nutrient modules (Mariangela Diacono and Francesco Montemurro, 2010). The integrated nutrient module would maintain the available potash or might increase as compared to the organic nutrient treatment which was confirmed with the present study results.

\section{Influence of different sources of nutrient modules on banana economics (Table 3)}

Banana crop is an exhaustive commercial horticultural crop which is grown for two-tothree years from single planting. The nutrient management plays a major role in its cultivation. The nutrient module which fetches higher returns as well as on par benefit: cost ratio as that of highest returns and highest benefit: cost ratio can be adopted for cultivation of banana.

The pooled economic analysis of treatments revealed that the lowest gross cost (Rs.1.29 lakh/ha) was incurred in the treatment $\mathrm{T}_{8}$ \{Poultry manure equivalent to $40 \% \mathrm{RDN}$ (8.96 t/ha) + $40 \%$ RDN through chemical fertilizer (urea $535.73 \mathrm{~kg} / \mathrm{ha}$ ) + Green manure (sunnhemp @ 8.88 t/ha) and Azospirillum (30.86 kg/ha) equivalent to $20 \% \mathrm{RDN}+\mathrm{PSB}$ (30.86 kg/ha) . The treatment $\mathrm{T}_{7}$ \{Vermicompost equivalent to $40 \% \mathrm{RDN}$ (24.20 t/ha) $+40 \%$ RDN through chemical fertilizer (urea $535.73 \mathrm{~kg} / \mathrm{ha}$ ) + Green manure (sunnhemp @ 8.88 t/ha) and Azospirillum (30.86 kg/ha) equivalent to $20 \% \mathrm{RDN}+\mathrm{PSB}$ $(30.86 \mathrm{~kg} / \mathrm{ha})\}$ recorded the highest gross returns (Rs.4.97 lakh/ha). The highest net returns $\{$ Rs.3.17 lakh/ha $\}$ in $\mathrm{T}_{10}$ \{Agrigold equivalent to $40 \% \mathrm{RDN}(10.52 \mathrm{t} / \mathrm{ha})+40 \%$ RDN through chemical fertilizer (urea 535.73 $\mathrm{kg} / \mathrm{ha})+$ Green manure (sunnhemp @ 8.88 t/ha) and Azospirillum (30.86 kg/ha) equivalent to $20 \% \mathrm{RDN}+\mathrm{PSB}(30.86 \mathrm{~kg} / \mathrm{ha})\}$ followed by $\mathrm{T}_{7}$ (Rs.3.04 lakh/ha). The highest benefit: cost ratio (3.42) was recorded in $\mathrm{T}_{12}\{\mathrm{RDF}=$ 617: 308.6: $925.8 \mathrm{~kg}$ NPK /ha) + Farmyard manure (@ $40.00 \mathrm{t} / \mathrm{ha}$ ) followed by $\mathrm{T}_{9}, \mathrm{~T}_{10}, \mathrm{~T}_{8}$ and $\mathrm{T}_{7}(3.04,2.85,2.78$ and 2.58 respectively) treatments. The treatment $\mathrm{T}_{7}$ (vermicompost combination) recorded moderate net returns (3.04 lakh/ ha) and B: C ratio (2.58) and is considered to be good due to the fact that if vermicompost is produced by farmers themselves the $\mathrm{BC}$ ratio can also be improved.

Bhalerao et al., (2009) reported that application of $100 \%$ recommended dose of NPK with 10 $\mathrm{kg}$ FYM per plant and bio-fertilizers (Azospirillum and PSB at $25 \mathrm{~g}$ each per plant) was found beneficial in terms financial returns with highest benefit cost ratio (1.48) in banana cv. Grand Naine.

Tangaselvabai et al., (2009) also reported that treatment with 100:30:330 g NPK/plant in 2 splits + Azospirillum was found to be superior for increased net profit (Rs/ha) and benefit: cost ratio. The integrated nutrient modules would be superior in obtaining higher net profit and on par benefit: cost ratio as compared to the control treatment $(100 \% \mathrm{RDF}+\mathrm{FYM})$.

Kuttimani et al., (2013b) reported that, higher gross returns of Rs. 3,63,850/- and Rs.3,85,600/- was recorded during 2010-11 and 2011-12 respectively with the application of 100 per cent recommended dose of fertilizer along with $40 \%$ Wellgro soil and the net return was higher (Rs. 2,25,403/- and Rs. 2,48,364/-) with the application of $100 \%$ recommended dose of fertilizer along with $40 \%$ Well grow soil. The benefit-cost ratio was higher (2.63) with $40 \%$ Well grow soil $+100 \%$ RDF. The results of the present study also indicated higher gross returns when integrated nutrient modules were followed. However, the organic nutrient modules registered lesser gross returns owing to the fact that the banana crop is an exhaustive crop which might not be coped up by organics alone.

Application of recommended dose of nitrogen in integrated manner would be a better nutrient 
module. Application of plants with vermicompost equivalent to $40 \%$ RDN (24.20 t/ha) $+40 \%$ RDN through chemical fertilizer (urea $535.73 \mathrm{~kg} / \mathrm{ha})+$ Green manure (sunnhemp @ 8.88 t/ha) and Azospirillum (30.86 kg/ha) equivalent to $20 \% \mathrm{RDN}+\mathrm{PSB}$ (30.86 kg/ha) $\left(\mathrm{T}_{7}\right)$ was most superior in increasing yield of banana besides reducing the crop duration followed by $\mathrm{T}_{10}$ (Agri-gold combination) and $\mathrm{T}_{11}$ (Bhumilabh combination) indicating the potentiality of organic manures when used in conjunction with chemical and bio- fertilizers.. The integrated nutrient modules favoured higher availability of soil nutrients which enhanced nutrient concentrations of NPK in different plant parts of banana and in turn the yield. The treatment $T_{7}$ recorded the highest gross returns (Rs.4.97 lakh/ha) and moderate net returns (Rs.3.04 lakh/ha). However, the B: $\mathrm{C}$ ratio was highest in control $\left(\mathrm{T}_{12}, 3.42\right)$.

\section{References}

Angelova, V. R., Akova, V. I., Artinova, N. S. and. Ivanov, K. I., 2013. The Effect of Organic Amendments on Soil Chemical Characteristics. Bulgarian Journal of Agricultural Sciences, 19 (5): 958-971.

Anonymous, 2011. National Horticulture Board. Department of Agriculture and Cooperation, Ministry of Agriculture, Govt. of India, New Delhi.

Athani, S. I., Hulamanai, N. C. and Shirol, A.M., 1999. Effect of vermicompost on maturity and yield of banana cv. Rajapuri (Musa AAB).South Indian Hort. 47(1-6): 4-7.

Bhalerao, V. P., Patil, N. M., Badgujar, C. D. and Patil, D. R., 2009. Studies on integrated nutrient management for tissue cultured Grand Naine banana. Indian J. Agric. Res., 43 (2):107-112.

Hazarika, T. K., Bhattacharyya, R. K. and Nautiyal, B. P., 2015. Growth
Parameters, Leaf Characteristics and Nutrient Status of Banana as Influenced by Organics, Bio-fertilizers and Bioagents. Journal of Plant Nutrition, 38 (8).

Hazarika, T. K., Nautiyal, B. P. and Bhattacharya, R. K., 2011. Effect of INM on productivity and soil characteristics of tissue cultured banana cv. Grand Naine in Mizoram, India. Indian J. Hort. 43(1): 30-35.

Kuttimani, R., Velayudham, K., Somasundaram E. and Muthukrishnan, P. 2013b. Effect of integrated nutrient management on yield and economics of banana. Global Journal of Biology, Agriculture and Health Sciences, 2(4):191-195.

Manivannan, K., and Selvamani, P., 2014. Influence of organic inputs on the yield and quality of fruits in banana cultivar 'Poovan' (Syn. Mysore AAB). ISHS Acta Hortic. 1018.

Mariangela Diacono, Francesco Montemurro, 2010. Long-term effects of organic amendments on soil fertility. A review. Agron. Sustain. Dev. 30 (2010) 401-422.

Nachegowda V, Senthil Kumar K and Raghavendra Prasad G C 2004. Effect of organic and inorganic fertilizers on growth, yield and quality of tissue cultured banana cv. Robusta. Proceedings of National Seminar on Banana Industry - Present Scenario and Future Strategies held at BCKV, FTC, Kalyani, West Bengal, $11-13^{\text {th }}$ June, 2004.

Patil, V. K. and Shinde, B. N., 2013. Studies on integrated nutrient management on growth and yield of banana cv. Ardhapuri (Musa AAA). J. Hort. For., 5(9):130-138.

Tangaselvabai, T., Gailice Leo Justin, C., Nirmal Johnson, S.B. and Jayasekhar, M., 2009. Influence of nutrients on qualitative and quantitative traits of banana. Indian $J$. Agric. Res. 43(4): 274-278.

\section{How to cite this article:}

Ganapathi, T. and Dharmatti, P.R. 2018. Role of Integrated Nutrient Modules on Yield, Economics and Soil Characteristics of Banana cv. Grand Naine. Int.J.Curr.Microbiol.App.Sci. 7(01): 2004-2012. doi: https://doi.org/10.20546/ijcmas.2018.701.242 